\title{
Turkey's Current Account Deficit Problem and Its Effects on the European Union Accession
}

\author{
Osman Zekayi ORHAN*ve Ebru NERGiZ**
}

\begin{abstract}
In developing countries, long-term current account deficits may cause serious problems in the economy. Turkey's current account deficit and the financing of this deficit is one of the most widely debated issues in recent years. There are two different views about the emergence of the current account deficit. According to the first view, the current account deficit is due to the increase in demand created by economic growth after the 2001 crisis. According to the other opinion, this deficit is a result of an overvalued domestic currency, which is created by high interest rates accelerating the flow of short-term speculative capital. Since the current account deficit is financed with debt, the increasing external debt of the country is threatening the future of the economy. In this study, firstly the current account deficit problem in Turkey and the factors affecting the current operations which play an important role in financing the short-term capital movements are explained. Secondly, the policies to ensure the current account balance are defined. Finally the effects of the current account deficit problem on the European Union accession is discussed.
\end{abstract}

Anahtar Kelimeler: Cari İşlemler Açığı, Türk Ekonomisi, Reel Döviz Kuru, Doğrudan Yabancı Yatırım, Avrupa Birliği Katılım Süreci

\section{Türkiye'nin Cari İșlemler Açığı Sorunu ve Avrupa Birliği Katılım Sürecine Etkileri}

$\ddot{0} \mathbf{z}$

Gelişmekte olan ülkelerde uzun vadeli cari açıklar ekonomide ciddi sorunlara neden olabilir. Türkiye'nin cari açık sorunu ve bu açığın finanse edilmesi son yıllarda en çok tartışılan konulardan biri olmuştur. Cari açığın ortaya çıkışı hakkında iki farklı görüş bulunmaktadır. İlk görüşe göre, cari açık 2001 krizi sonrasında oluşan talep artışına bağlı olarak oluşmuş̧tur. Diğer görüşe göre bu açlk

\footnotetext{
${ }^{*}$ Prof. Dr., Faculty of Economics, Administrative and Social Sciences, Istanbul Gelişim University, ozorhan@gelisim.edu.tr

${ }^{* *}$ Assistant Professor., Vice Director at School of Applied Sciences, Istanbul Gelişim

University, energiz@gelisim.edu.tr
} 
kısa vadeli spekülatif sermayenin akışını hızlandıran yüksek faiz oranları sonucu oluşan aşırı değerlenmiş yerel para biriminin bir sonucudur. Cari açık borç yoluyla finanse edildiği için ülkenin artan dış borcu ekonominin geleceğini tehdit etmektedir. Bu çalışmada, öncelikle Türkiye'nin cari açık sorunu ve kısa vadeli sermaye hareketlerini finanse etmekte önemli rol oynayan operasyonları etkileyen faktörler açıklanmaktadır. İkincil olarak, cari açık dengesinin sağlamak için politikalar tanımlanmaktadır. Son olarak Türkiye'nin cari açık sorununun Avrupa Birliği üyelik sürecine etkileri tartışılmaktadır.

Key Words: Current Account Deficit, Turkish Economy, Real Exchange Rate, Foreign Direct Investment, European Union Accession

\section{Introduction}

A country's international trade in goods and services and international borrowing and lending are recorded in its balance of payments accounts. In other words, the current account balance is a measure of a country's transactions with the rest of the world (Ickes, 2008). The balance of payments consists of two main accounts: the current account and the financial account. The current account measures the change over time in the sum of three separate components: the trade account, the income account, and the transfer account. The trade account measures the difference between the value of exports and imports of goods and services. A trade deficit occurs when a country imports more than it exports ${ }^{1}$.

Current account can be defined in different ways. It is the addition of net factor payments and net transfers from abroad to the balance of trade of total goods and services. In other words, it can be defined as the subtraction of consumption expenditure from gross spendable income. From another point of view, current account is the level of domestic savings to meet investments. Finally, in analyzing savings investments one should take into consideration not only the assets acquired by a country's residents through external lending and borrowing but also the international flow of financial assets. Accordingly, current account is also acknowledged as the change in new foreign assets compared to other

${ }^{1}$ Jill A. Holman, 'Is The Large U.S. Current Account Deficit Sustainable?' Economic Review, First Quarter: 2001, p. 5-23. 
countries $^{2}$. In other words, the current account of the balance of payment refers to the monetary value of international flows associated with transactions in goods and services, investment income and unilateral transfers ${ }^{3}$.

The financing of a country's accounts, which is the balance between foreign income and expenses in production factors, and merchandise trade in the real sector of the economy, is the most important indicator of foreign exchange gap/surplus. Accounts are financed with foreign direct investment, portfolio investments and external financing through external borrowing 4 . The aim of this study is to identify the causes and consequences of the current account deficit in the Turkish economy and to analyze the effects of the current account deficiton on Turkey's European Union accession.

\section{The Current Account Deficit}

Movements in the current account deficit are may occur due to movements in the trade deficit. The current account deficits may be financed by net capital inflows from abroad. Finally, the exchange rate is related to the current account because international transactions (including trade in goods, services, and financial assets) generally require exchanging Turkish Liras for foreign currencies ${ }^{5}$.

There is a strong inverse relationship between account deficits and foreign capital flows. The financial capital income within such capital flows (excluding foreign direct investments) naturally increases debt. In this respect, a problem that is as important as the size of a country's account deficits is the type of financing used with deficits. External borrowing from international organizations, foreign banks and governments lead to an increase in the country's outstanding external debt. Official reserves which is the second way to offset current deficits is excluded from this study.

2 Fatih Yücel \& Rüstem Yanar, “Türkiye'de Cari İșlem Açlkları Sürdürülebilir mi? Zaman Serileri Perspektifinden Bir Bakış", Çukurova Üniversitesi Sosyal Bilimler Enstitüsü Sosyal Bilimler Dergisi, 14 (2), 2005, s. 483-492.

${ }^{3}$ Robert Carbaugh, International Economics Ohio: South Western College Publishing, 7th Edition, 2000.

${ }^{4}$ Ceran Zeynep Zafir \& Funda H. Sezgin, 'Analysis of the Effects of Foreign Direct Investment on the Financing of Current Account Deficits in Turkey' International Journal of Business and Social Science, 3(10), 2012, p. 68-78

${ }^{5}$ Holman, 'Is The Large U.S. Current Account Deficit Sustainable?' Economic Review, First Quarter, 2001, p. 5-23.

Sayfa/Page | 139

İGÜSBD Cilt: 1 Sayı: 1

Haziran / June 2014 
Financing current account deficits with foreign direct investment and longterm foreign currency inflows may seem relatively less problematic compared to the hot money flow which increases short-term debts and external debts 6 .

Sayfa/Page | 140 İGÜSBD Cilt: 1 Sayı: 1 Haziran / June 2014

As widely known, a large volume of hot Money, which wants to take advantage of high interest rates and therefore moves towards speculative areas, reduces the profitability of exports due to overvalued domestic currency and increased deficits. When the hot money is out of the system after disturbing the balance between interest and exchange rates, it drags a country's economy to larger dilemmas. The country therefore becomes more dependent on imports and steers away from being a production economy to a consumption economy. Furthermore, a large increase in current account deficits is another factor which lets hot money escape from a country. Such an economic growth results in production increase of cheap import input, capital inflow and a rise in real exchange rates. Increased investment rates and high growth rates provided by foreign investment resources lead to current account deficits.

\section{The Current Account Deficit in the World and Turkey}

Global economic disparity is unanimously accepted as one of the most significant factors in the outbreak of the 2008-2009 global crisis. The greatest pre-crisis imbalance was the huge current account deficit in the United States, which had been financed by the current account surpluses of Asian countries, particularly China, as well as by exporting countries in the European Union. The current account deficit in the American economy, which had been increasing rapidly since 1998, reached its highest level of $\$ 800$ billion in 2006 . With fluctuations in the mortgage markets occurring simultaneously that same year, the American current account deficit was reduced by half after the crisis had spread globally in 2009. The U.S. was not alone in such a sudden change caused by the economic crisis, since other countries with chronic current account deficits, including Turkey, went through a similar experience. However, while the global crisis started to lose its grip on Turkey in 2010, the current account deficit in Turkey actually increased, even exceeding its highest precrisis level 7 .

${ }^{6}$ Erinç Yeldan, Küreselleşme sürecinde Türkiye ekonomisi, 12. bs, İstanbul: İletişim Yayınları, 2006.

${ }^{7}$ Sumru Öz, 'Current Account Deficit in Turkey: Macro and Micro Reasons and Suggested Solutions' International Investors Association YASED, 3-4, 2011. 
Indeed, in terms of the ratio of current account balance to gross domestic product (GDP), Turkey is the OECD country with the third highest deficit after Greece and Portugal, which is a fact that reveals the necessity of taking urgent measures. After all, the global crisis has become a debt crisis that continues to affect those two countries, which have the same level of current account deficit as Turkey although for a longer time period of time. Along with the monetary and Exchange rate policies applied yearly and the dependence of industry on external inputs deepened this problem. Moreover, the size of imports has had a negative effect on the Turkish economy, which carries a high unemployment rate.

Energy dependency and the low saving rates of the young population are two main causes of the current account deficit in Turkey. Turkish economy is highly dependent on energy imports due to a shortage of local sources. The detrimental effect of high energy bill becomes especially apparent at times when the price of energy related commodities rise which puts the cyclical effect to the forefront. Also as a country with young population, low saving rates is another major structural cause of the current account deficit.

When we look at the historical development of the current account deficit in Turkey, from 1974 to 2010, the current account deficit reached historically high levels, especially after the 1980s when Turkey changed its focus from an import substitution system to an outward-oriented growth one, and in the years just before economic crises hit, during which GDP shrank. The ratio of the current account deficit to GDP was 3.6 percent just a year before the crisis of 1994 and 4.9 percent before the crisis of 2001. With its ratio to GDP exceeding 5 percent from 2004 to 2008, the current account deficit was sustained for longest time in Turkey's history. The major causes of this were post-crisis reforms, which enabled the readjustment of basic political indicators, as well as the initiation of membership negotiations with the EU in 2005, both of which lead to the emergence of different drivers. For instance, the ratio of net international direct investment inflow to GDP increased to 3.8 percent in 2006 from an average of less than 1 percent in the 1996- 2005 period. Indeed, some studies suggest that the current account deficit can be sustained-at least for a time-by increasing the ratio of international direct investments to GDP. From 2004 to 2008, unlike during other pre-crisis periods, the current account deficit resulted from private sector investment and

Sayfa/Page | 141 İGÜSBD Cilt: 1 Sayı: 1 Haziran / June 2014 
consumption demand rather than from a decreased savings ratio and large budget deficits.

However, throughout the global crisis, which started in September

Sayfa/Page | 142 İGÜSBD Cilt: 1 Sayı: 1 Haziran / June 2014 quarter of 2009-shrunk the most not only among the top twenty economies in the world, but also among the major emerging-market economies. This exemplifies the highly adverse effects that any global liquidity and/or loan crisis can have on countries in significant need of external financing-including Turkey-regardless of how sound their own domestic macroeconomic balances may be.

In Turkey, annual energy imports of approximately 60 billion dollars are often blamed for the high current account deficit. They are undoubtedly a factor, but South Korea also imports almost all its energy but somehow manages a strong current account surplus ${ }^{8}$.

The government recognises the problem and has introduced a number of prudent measures such as providing equity investment incentives, introducing measures to increase private increasing private savings, encouraging renewable energy, and establishing two nuclear energy plants in an effort to correct the external imbalances.

Turkey's 77.2 billion dollars current account deficit of 2011 corresponds to about 10 per cent of GDP. Although a same deficit ratio may represent different degrees of impact and danger to different countries, this is by any account obviously a very large percentage constituting a serious factor of vulnerability for the economy. In terms of magnitude, 77.2 billion dollars corresponds to the second highest deficit in the world after the US.

The sources of financing of the deficit also reflect weaknesses. Foreign direct investment (FDI) constituted only 21 percent of the total of 77.2 billion dollars in 2011. One billion dollars were used from the reserves. The net errors and omissions item was as much as 11.9 billion dollars. The composition didnt improve much in the first four months of 2012 and the net errors and omissions item for this period reaches 2.9 billion dollars. This is too large an amount for such an item. Looking at the structure of the deficit, one notices that its main source is the trade balance.

${ }^{8}$ David Edgerly, 'Turkey's Current Account Deficit is Economy's Achilles Heel', Financial Times, 27 November 2013. 
Tha balance of services, goods and income was 79 billion dollars in 2011 . This in turn reflects a high import dependency in the Turkish economy9.

The most significant aspect of this dependency concerns manufacturing production for the domestic as well as export markets. According to the figures, indicated by the Minister of the Economy the rate of interest increased from 40 percent in 2010 to 43 percent in 2011. For example it is 56 percent in automobile production, 30 percent in the manufacture of machinery. So, even a high rise in exports does not help sufficiently toward containing the deficit. This situation reflects the need to upgrade the technology content hence the competitiveness of industries and the economy. It is also to be noted, in this context, that so far FDI has to a considerable extent opted for nontradeable sectors and this limited the benefits it brought in terms of an increase in competitiveness and export potential. Other factors of vulnerability, especially for the forthcoming period, likely to elapse in an atmosphere of uncertainty in Europe include the rise of short term external debt which went up by 13.6 per cent between the end of 2011 and April 2012, reaching 95.2 billion dollars.

One of the main fundamental sources of a dangerously high current account deficit in Turkey is the saving rate which is worryingly decreasing. The saving rate has in fact reached a level as low as 12 per cent in 2011. The government is aware of the need to increase the saving rate and has recently adopted a scheme in which a sizeable public contribution is provided to new private pension accounts so as to support private savings. The declared aim of a new incentives scheme for the industry introduced by the government is to reduce the import dependency of the economy. The effectiveness of the incentive policy will depend on sevaral factors including the other elements of the overall economic policy. Despite these moves the present economic policy structure is unable to ensure high growth with a reduced level of current account deficit. The trend of overvaluation of the TL is also detrimental to the current account balance. All these factors associated with a high current accounts deficit structure have also negative impacts on the sustainability of the financing of development. The Government's attitude can be summarised as follows: "Our policies are so effective that we can easily deal with any dangerous situation, so the current account balance deficit is not a serious cause for

${ }^{9}$ Yusuf Işık, “Turkey's Current Account Balance: A Real Problem”, İstanbul: Reflections Turkey, 2012, http://www.reflectionsturkey.com/?p=657.

Sayfa/Page | 143 İGÜSBD Cilt: 1 Sayı: 1 Haziran / June 2014 
worry, and in any case it is decreasing". This is not a reassuring stand, on the contrary it increases the vulnerability caused by the deficit. The policy instruments needed to achieve similtaneously high growth and a low current account deficit comprise: an innovation and technological

Sayfa/Page | 144 İGÜSBD Cilt: 1 Sayı: 1 Haziran / June 2014 development based investment policy and pattern in line with transformation toward the knowledge economy; in a related way, a set of measures ensuring simultaneously on the one hand the mobilisation of existing vast labour resources, and on the other hand resorting substantially to knowledge intensive high technology production; upgrading the education system accordingly; raising significantly the saving rate through additional policies including in taxation; a more rules based economic governance structure (ref. my article titled "The Decree Laws of 2011: a Dangerous Course", published in May 2012 issue of Reflections) so as to restrict rent and facilite competitiveness enhancing developments; in a similar vein, improving the quality of financing; flexible and at the same time more effective policy instruments relating to capital flows so as to restrict overvaluation; encouraging actively FDI to choose tradeable sectors and higher technology activities.

A working paper prepared by the Turkish Central Bank in 2010 points to a deeper reason for Turkey's heavy dependence on imports. The report demonstrates that, as the Turkish economy developed beyond the traditional labour-intensive industries like textiles, manufacturing required more raw materials and sophisticated machinery and equipment, most of which continued to be imported. The paper surveyed 145 leading manufacturing companies in Turkey and found that in key sectors, such as electronics and metals, imports accounted for more than 80 percent of the total expense of raw material and equipment. In petrochemicals, imports account for 87 percent of the total inputs. In the automotive sector, imports amount to almost 60 percent of total inputs. The paper lists several reasons, including the relatively strong Turkish lira from 2002-10 and the customs union with the European Union, for the predominance of imported raw material and equipment but the main reason given by the companies is the lack of an adequate domestic supply chain. The required material, from coking coal to sophisticated chip sets, either does not exist at all or not in sufficient amounts in the domestic market to offset the imported goods. One result of the reliance on imported raw material and equipment is to reduce the value-added domestic content of Turkish exports. 
The bank's paper cites the example of the television industry. Turkish-made TV sets account for about 50 percent of the EU market, but important components of those televisions are imported into Turkey. In theory, the 15 percent decline of the Turkish lira in 2013 should narrow the current account deficit by encouraging exports. When those same exports, however, contain so many imported components the positive impact may be limited.

Given the economy's structure, it is difficult to see how any growth, driven by domestic demand or exports, can avoid increasing the current account deficit. Given the government's strong aversion to interest rate adjustments, that tool has been removed from the policy toolbox. Yet most of the government's measures will take time to become effective. The critical question is whether the global economic situation will continue to give Turkey the time it needs ${ }^{10}$.

In 2013, the current account deficit (CAD) in Turkey widened as domestic demand accelerates, and the external financing requirement remains high. In the first four months of the year, the CAD increased by 17.1 percent year on year. However, adjusting for the gold trade the yearto-date CAD was down by 5.4 percent year-on-year thanks to a 27.6 percent year-on-year surge in tourism revenues. As of April 2013, the 12month rolling current account deficit amounted to $\$ 51.3$ billion (6.2 percent of estimated $2013 \mathrm{GDP}$ ) and the CAD remains mostly financed by portfolio inflows. FDI inflows were muted in the first four months of 2013 at just $\$ 3.1$ billion compared to $\$ 5$ billion a year earlier. As domestic demand picks up, the CAD is expected to widen further in the coming months and amount to 6.9 percent of GDP in 2013 as a whole, up from 6.1 percent in 2012. As of April 2013, Turkey's total external financing requirement remains high at an estimated $\$ 220$ billion (more than 25 percent of GDP) in the coming 12 months.

The Relationship Between Foreign Direct Investment and the Current Account Deficit

As current account deficit leads a country with savings deficit is to import savings from abroad, the relationship between current account balance and foreign capital investments can be explained by the

${ }^{10}$ Edgerly, 'Turkey's Current Account Deficit is Economy's Achilles Heel', Financial Times, 27 November 2013.

Sayfa/Page | 145 İGÜSBD Cilt: 1 Sayı: 1 Haziran / June 2014 
Sayfa/Page | 146 İGÜSBD Cilt: 1 Sayı: 1 Haziran / June 2014 relationship between savings and investment. In this case, the rise in domestic interest rates encourages capital inflow, and the balance of financial accounts payments will have a surplus ${ }^{11}$. As for the host country, the first effects of foreign capital investment on foreign trade rates and balance of payments are widely considered positive. The effects of foreign capital investments are very important in remedying the lack of capital, closing the domestic savings gap and increasing foreign exchange revenue in Turkey and in other developing countries with similar economic structure. In addition, foreign direct investment has positive effects, as it raises production and employment, transfers technology, brings dynamism to domestic economy, increases domestic competition, provides knowledge on foreign markets and management, and adds to the tax revenue for local governments. On the other hand, an increased foreign control on the economy has negative effects as it forms binary structures, makes it difficult to follow an independent industrial policy, distorts competition for national companies, and even pushes local firms out of the market. Furthermore, the host country cannot implement its foreign trade policies. Foreign exchange costs increase as foreign firms transfer profits to their own countries. In some cases, firms become dependent upon technology imports when Research and Development (R\&D) operations are run in company headquarters. As foreign-dependency increases, transfer pricing problems may occur ${ }^{12}$. In an environment of global awareness especially in recent years, pollutant production techniques, sustainability of ecological balance, and waste become problems.

Foreign direct investments in Turkey gained momentum with the transition to a export-oriented industrialization policy after the 1980s. However, in the 1990s foreign direct investments slowed down and became static. Due to high inflation and a very unstable environment, the Turkish foreign capital policy disregarded technology transfer, technical training, R\&D, foreign market links, and local hinterland and metropolitan industries. Instead it favored short-term profit expectations, geographical proximity and low labor costs. Renovation investments as well as expansion and capital investments predominated the period after the 1994 crisis, when the Turkish Lira was overvalued due to very high real interest rates (Kaya 2010). Actual capital inflow was in the form of FDI in 1990-

${ }^{11}$ Mahfi Eğilmez \& Ercan Kumcu, Ekonomi Politikası: Teori ve Türkiye Uygulaması, 11. bs., Istanbul: Remzi Kitabevi, 2007.

${ }^{12}$ Coşkun Can Aktan, İstiklal Y. Vural, Yeni Ekonomi ve Yeni Rekabet, Ankara: Ajans Türk Basın ve Basım A.Ş., 2004. 
1999, when the lowest inflow was 817 million USD whereas the highest was 1.242 billion USD. The most important reason why authorized capital is different from actual inflow is that foreign companies with an authorization to invest brought only a small amount of the capital when they founded the company and let the rest of the amount spread over time ${ }^{13}$.

80 percent of the current account deficit in 1992 and 10 percent in 1993 was covered by foreign direct investment. In 1994, 1998 and 2001 current accounts balance had a surplus, but showed a fluctuating course in other years. Based on FDI inflows, 45 percent of the 221 billion USD current deficits in 1992-2010 were financed directly by direct investments. In net values, a cumulative of 86 billion USD FDI inflow financed 39 percent of the current deficit in the same period. When portfolio investments and other investments excluding FDI improved, the current account deficit increased, and when they lessened, the current account deficit decreased. As mentioned above, periods of crisis, when the economy contracted, were periods when the current account balance had a surplus.

By the 2000s, mergers and acquisitions started to build an overall view for foreign direct investments. The share of service sector in particular was very high compared to the manufacturing industry in this period. Another characteristic of the investments was that they internationalized R\&D expenditures. Another important structural change in the flow of FDI was a result of the acquisitions made by financial institutions, such as private equity companies and some hedge funds ${ }^{14}$. The fluctuation of foreign investment in Turkey in 2000s' reveals itself especially with a hard drop in the 2001 crisis. Following the crisis, monetary policies supported by the fiscal discipline and diminution in economic and political uncertainties, the policies aiming at improving the investment environment and the positive impact of the global markets accelerated capital inflow. The legal regulations in 2003 concerning foreign capital (Foreign Investment Law No. 4875) and the reduction of bureaucratic procedures in founding a company increased the number of newly established companies.

\footnotetext{
${ }^{13}$ Tezer Öcal, Türkiye Ekonomisi, Ankara: Savaş Yayınevi, 2004.

${ }^{14}$ Erhan Aslanoğlu, 'Türkiye'nin Yabancı Sermaye Çekmede Etkinlik Arayışları' İ. Öztürk (Ed.), Türkiye'nin Küreselleşmesi, Fırsatlar ve Tehditler, İstanbul: İstanbul Ticaret Odası Yayınları, 2008, s. 85-104.
}

Sayfa/Page | 147

İGÜSBD

Cilt: 1 Sayı: 1

Haziran /

June 2014 
Sayfa/Page | 148 İGÜSBD Cilt: 1 Sayı: 1 Haziran / June 2014

From a sectorial point of view, the share of service sector in foreign direct investments was outstandingly large. The large share of the service sector is not a situation unique to Turkey. Service sector still has a large share globally. In the 2000s, the decline in foreign direct investment which also resulted from the economic conjuncture had a sectorial effect and lead to a downward trend. In recent years Turkey has focused on privatization in order to accelerate foreign capital inflow. For example, privatizations yielded approximately 8 billion USD in 2005 and 2006. In 2007 the figure dropped to about 4.2 billion USD and rose to 6.3 billion in 2008. These institutions were acquired mostly by local investors. Foreign investors accounted for 1.5 billion USD in 2005 and 1.768 billion USD in 2006.

Even though Turkey received a serious amount of foreign capital inflow after 2000, a content analysis shows that these inflows did not contribute to the of payments as much as the economic growth. An important part of foreign capital investments after 2005 were in the form of mergers and privatizations. These activities brought to Turkey a substantial amount of foreign exchange. In 2007 the 20 billion USD foreign direct capital threshold was exceeded. The reason why there were many FDIs (worth 15 billion USD) in Turkey in 2008 despite the crisis is that almost all investments were mergers and acquisitions. For example, the total of 9.681 million USD foreign direct investments was made up of acquisitions: 3.970 million USD in finance sector and 3.350 million USD in communications-telecommunications sector. 1.841 million USD was from acquisitions in the field of real estate and 1.5 billion USD were from privatizations.

In 2007, as a result of a high amount of capital inflow in the form of direct portfolio investment and other investments, financial accounts had a surplus of 36.6 billion USD.

This positive trend in the financial account of balance of payments took a reverse direction in September 2008 due to recurrent global uncertainties, and this downward trend gained impetus in 2009. The global recession which began in 2008 became more apparent in 2009 with sharp declines in financial accounts. The changes in the financial accounts indicate that capital flow into Turkey changed in favor of direct investments and long-term capital instead of short-term capital inflow. Structural reforms after 2007 in particular, economic stability, large foreign exchange reserves of the Central Bank of the Republic of Turkey (CBT), the floating exchange rate regime and the strengthening of the 
banking system are among the factors that limited the effects of a possible capital outflow on the financing of the current account deficit (Ministry of Finance Report, 2007). The accession negotiations with the European Union increased the reliability of the Turkish economy in international markets, accelerated direct capital inflow and improved national investments.

The global financial crisis affected foreign direct investments (FDI) negatively especially in 2009; however, a recovery tendency was obtained in 2010 and this tendency continued in 2011. The FDI Inflows have fallen from 19.504 billion dollars in 2008 to 8411 billion dollars in 2009. The FDI inflow to Turkey reached to 15.9 billion dollars in 2011. According to the World Investment Report (2013) , FDI inflow to Turkey was 12.4 billion dollars with a 23 percent decrease compared to 2011 in line with the global FDI flows.

\section{Portfolio Investment and Debt in the Financing of Current Account Deficits}

The course of portfolio investments in the financing of current account deficits in Turkey can be said to be quite undulating. Portfolio investments were almost up to twice the current account deficits in 1992 and 1999 while such investments had a negative value in 2008, which explains this unstable pattern. In 1992-2010 a cumulative sum of 68 billion USD portfolio investments had a net value of 43 billion USD, and financed 19 percent of net account deficits and 31 percent of portfolio investment inflow. In Table 4, Portfolio Investments are given as liabilities (PIL), net portfolio investments (PIN) and current account balance (CAB).

Short-term capital left Turkey due to the global crisis of 2008-2009 and turned international capital flows into "net outflow". The two most important forms of outflow were net external debt principal payments and flight of hot money. In 2008 Turkey experienced a new capital outflow in the form of portfolio investment worth 5 billion USD. The inflow recorded in 2009 was only 196 million USD. The importance of private sector debt in the financing of current account deficits stems from the fact that private sector debt could cover 84 percent of the deficits. In this period, the cumulative sum of private sector debt was 186 billion USD, and 154 billion USD in net values. The figure is in a position to finance 69 percent of current account deficits. The effects of debt creating capital inflow in the financing of current account deficit stem less from portfolio investments of

Sayfa/Page | 149 İGÜSBD Cilt: 1 Sayı: 1

Haziran / June 2014 
securities and FDIs than debentures, other capital inflow and IMF loans until 2003. After 2003, long-term loans started to gain importance.

\section{Real Exchange Rate and the Current Account Deficit}

Sayfa/Page | 150 İGÜSBD Cilt: 1 Sayı: 1 Haziran / June 2014

Until the end of the 1970s, Turkey followed a fixed and multiple exchange rate policy while experiencing relatively high inflation rates. The policy led to a loss of competitiveness and eventually to the foreign exchange crisis of the late 1970s. The gross national product (GNP) shrank by 0.5 percent in 1979 and by 2.8 percent in 1980 .With the stabilization measures of 1980, Turkey devalued its lira by 100 percent and eliminated the multiple exchange rate system, except for imports of fertilizers and fertilizer inputs. After May 1981, the exchange rate was adjusted daily against major currencies to maintain the competitiveness of Turkish exports.

Multiple currency practices were phased out during the first two years of the 1980 stabilization program, and the government pursued a policy of depreciating the real exchange rate (RER) - on average by about 6 percent annually over the period 1980-88. In January 1984, domestic commercial banks were allowed to engage in foreign exchange operations within certain limits, and restrictions on foreign travel and investment from abroad were eased and simplified. Determination of the exchange rate was further liberalized by permitting banks to set their own rates within a specified band around the central bank rate. In August 1988, major reform was introduced, and a system in which the market set foreign exchange rates was adopted. In 1989 foreign exchange operations and international capital movements were liberalized entirely. A drawback of the RER depreciation policy pursued during the 1980s was the decline in real wages, measured in terms of foreign currency. By the second half of the 1980s, popular support for the government had begun to fall off. In the local elections of March 1989, the governing political party suffered heavy losses. To increase political support, the government conceded substantial pay increases during collective bargaining in the public sector. Pressure then built up in the private sector to arrive at similarly high wage settlements, real wages began to increase, and the RER started to appreciate. According to the government, the appreciation of the RER after 1989 stemmed from market forces.

During the 1990s, Turkey's public finances deteriorated considerably. The large public sector deficits were financed by borrowing 
from the market at very high real interest rates. Significant capital flowed into the country because it was offering not only high real interest rates but also the prospect of steady real appreciation of the exchange rate. Thus the government's implicit commitment to the RER appreciation insured the private sector, domestic and foreign, against currency risk. It encouraged capital inflows from abroad and lending to the public sector, giving rise to the phenomenon of large, arbitrage-related, short-term capital inflows.

The policy pursued during the first half of the 1990s was not sustainable. By 1993 the currentaccount- deficit-to-GDP (gross domestic product) ratio had reached 3.6 percent. In 1994 the country faced balance of payments crises from which the GDP shrank by 5.5 percent. But with the introduction of stabilization measures, the trend in the RER reversed. The RER depreciated by 64 percent during January 1994 and April 1994. The country had to reverse its economic policies, however, because of the relatively weak coalition governments. The RER began to appreciate again after April 1994, and by September 1995 it had appreciated by about 23.5 percent. Between 1995 and 1997, the economy went through a boom period of above-trend growth,only to find itself badly hit in 1998 by the Russian crisis. In August 1999, a severe earthquake hit the Marmara area of Turkey, and another large shock hit the Bolu area in November 1999. Because of these shocks, real GDP shrank by 4.7 percent in 1999. At the end of that year, Turkey embarked on an ambitious stabilization program. Central to the program has been the policy of using a predetermined exchange rate path as a nominal anchor for reducing inflationary expectations. During 2000, the RER appreciated considerably, which aggravated further the current account deficits, leading to concerns about the sustainability of the exchange rate regime. The current accountdeficitto-GDP ratio reached 4.9 percent in 2000 . This episode ended with a severe currency crisis in February 2001. There was a serious run on the Turkish lira (TL), interest rates skyrocketed, and foreign exchange reserves began to decline rapidly. The government decided to abandon the crawling peg regime and to float the currency. The exchange rate then depreciated sharply.

On May 15, 2001, the IMF increased its assistance under a new standby arrangement. This program aimed to strengthen the balance of public finances in a way that would prevent deterioration in the future. During 2001, Turkey introduced a set of structural reforms. But the terrorist attacks of September 11, 2001, threatened the progress of the

Sayfa/Page | 151 İGÜSBD Cilt: 1 Sayı: 1 Haziran / June 2014 
Sayfa/Page | 152 İGÜSBD Cilt: 1 Sayı: 1 Haziran / June 2014

reforms. Turkey responded with a strengthened medium-term program intended to clean up the banking sector, consolidate fiscal adjustments, and achieve disinflation, and in February 2002 the IMF approved a three-year standby credit for Turkey to support the government's economic program. During 2001, the GNP contracted by 9.5 percent, and the loss in employment was put at more than 1 million. Toward the end of 2001, the RER began to appreciate again. With the appreciation of the RER, considerable economic recovery was observed during 2002-04. Currency crises arose in the late 1970s, 1994, and 2001. By October 2004, the annual current account deficit had reached $\$ 14.17$ billion, and the currentaccountdeficit- to-GDP ratio had increased to about 5 percent by the third quarter of 2004.

\section{The Effects of Turkey's Current Account Deficit Problem on} European Union Accession

The current account deficit is an important aspect of the economic criteria for Turkey's European Union accession. According to the 2013 European Union's progress report of Turkey, regarding the economic criteria, Turkey is a functioning market economy. It should be able to cope with competitive pressure and market forces within the Union in the medium term, provided that it accelerates the implementation of its comprehensive structural reform programme.

Following strong growth rates of around 9 percent in the previous two years, Turkish GDP growth slowed down to 2.2 percent in 2012. This was accompanied by a rebalancing of growth from domestic demand to foreign trade, a temporary narrowing of the current account deficit, and a decline of inflation. In the first half of 2013, GDP growth strengthened again to 3.7 percent. At the same time, the current account deficit has widened again and consumer prices have reaccelerated.

Public debt as a share of GDP has continued to recede and is now clearly below 40 percent. Since May, due to domestic and global factors, financial markets have come under pressure which led to immediate reactions by the central bank with a view to stabilising the exchange rate and containing capital outflows.

Turkey's recent economic performance illustrates both the high potential and the continuing imbalances of the economy. On the external side, the reliance on sustained capital inflows to finance a large structural 
current account deficit makes Turkey vulnerable to changes in global risk sentiment, resulting in large exchange rate fluctuations and boom-bust cycles in economic activity. Addressing this vulnerability calls for measures to increase national saving and fiscal policy has an important role to play in this respect. The adoption of a fiscal rule would enhance budget transparency, provide an important fiscal anchor and enhance credibility. Relatively high inflation continues to be a major challenge. A rebalancing of the macroeconomic policy mix would be helpful to ease the burden on monetary policy. For the medium to longer term, it is essential that the functioning of the markets for goods, services and labour is improved through structural reforms to increase international competitiveness.

According to the report, the current account has continued to register a large deficit, which leaves the Turkish currency vulnerable to sudden loss of investor confidence. In conjunction with the softening of domestic demand and strong export growth, the current account narrowed significantly from 9.7 percent of GDP in 2011 to 6.0 percent in 2012. Most importantly, imports of goods declined by 1.5 percent, while exports of goods surged by 13.9 percent in value terms. The balance of payments data for the first half of 2013 suggest a reversal of this trend, as goods exports increased much more moderately (2.8 percent year-on-year) while goods imports recovered strongly (7.1 percent). The 12-month cumulative current account deficit has risen back up to 6.6 percent of GDP. However, Turkey's foreign trade data have been distorted by strong fluctuations in exports and imports of non-monetary gold in recent years. Net exports of gold in 2012, corresponding to 0.7 percent of GDP, were succeeded by large net imports in the first six months of $2013^{15}$.

The bulk of the current account deficit was financed by portfolio investments in 2012, while net inflows of foreign direct investments covered a relatively small proportion (17.8 percent) of the deficit. The high degree of dependence on shorter-term capital inflows exposes Turkey to changes in global risk appetite. The central bank's foreign exchange reserves increased from $€ 56$ billion at the end of 2011 to $€ 78$ billion at the end of 2012 and further to $€ 94$ billion at the end of June 2013 (16 percent of GDP). The gross foreign debt rose by 10.8 percent in the course of 2012, but expressed as a proportion of GDP it fell by 1.8 percentage points to 42.5 percent. Overall, the external imbalances have remained significant and

${ }^{15}$ European Commission, Staff Working Document Turkey, 2013, Brussels: European Union, 16.10.2013 SWD (2013) p. 417.

Sayfa/Page | 153

İGÜSBD

Cilt: 1 Sayı: 1

Haziran /

June 2014 
their short-term financing makes the country vulnerable to sudden changes in global investor sentiment.

The current account deficit widened significantly in the first seven

Sayfa/Page | 154 İGÜSBD

Cilt: 1 Sayı: 1 Haziran / June 2014 months of 2013. Goods exports were only 2.7 percent higher year-onyear in this period whereas goods imports rose by 7.6 percent. In July, the 12month cumulative current account deficit amounted to USD 55.8 billion which corresponds to 6.8 percent of GDP at the average exchange rate in the period compared to 6.0 percent last December. It has to be recalled that Turkey's external trade performance has been distorted by strong fluctuations in exports and imports of non-monetary gold in recent years. Net exports of gold in 2012, corresponding to 0.7 percent of GDP, have been succeeded by large net imports in the current year. The bulk of the current account deficit continued to be financed by inflows of portfolio investments (although these turned into outflows in June and July). Net inflows of foreign direct investments covered 12.2 percent of the deficit in the first seven months of 2013. The central bank's foreign exchange reserves fell from €94 billion at the end of June to $€ 81$ billion at the end of August (14.4 percent of GDP). Gross external debt has surged from 42.5 percent of GDP at the end of 2012 to 47.8 percent at the end of the second quarter, mainly due to the lira's depreciation in May and June ${ }^{16}$.

\section{Conclusion}

The expected strengthening of the domestic demand calls for a policy mix geared towards current account sustainability in a context of benign inflation. Structural policies can be helpful in supporting such objectives. There is scope in Turkey for a further strengthening of competition through continuing liberalization of product and service markets, especially in non-traded services, that could also facilitate the monetary stance $^{17}$ (European Union, 2013). Beyond the new incentive system adopted in 2012 and the implementation of the new Commercial Code as of 2013, structural reforms to strengthen the investment climate would not only be conducive to higher private investment, competitiveness and growth but also attract foreign savings in the form of foreign direct

16 European Commission, EU Candidate and Pre-Accession Coumtries

Economic Quarterly CCEQ 3/2013, European Union, 2013.

17 European Union, European Economy Occasional Papers 157, July 2013, 2013

Pre-accession Economic Programmes of Iceland, The Former Yugoslav Republic of Macedonia, Montenegro, Serbia and Turkey EU Commission's Overview and Assessmets. 
investment, thus ensuring a more sustainable financing of the current account. In this context the crucial steps to take will be an up-grading and better use of human capital through the pursuit of the education agenda and the deepening and widening of labour market reforms.

Turkey's large external financing needs continue to pose a threat to macro-financial stability, in spite of the recent reduction in imbalances. The current account deficit has adjusted at a significant pace, and fell from 9.7 percent of GDP in 2011 to 5.9 percent of GDP in 2012. In tandem, the quality of the financing has somewhat improved, albeit risks remain substantial as debt-creating flows and short-term borrowing stil represented over half of the total inflows in the first nine months of 2012. While attracting more FDI can limit volatility, the excessive reliance on foreign financing can be reduced by promoting domestic savings. While further financial sector reforms might be worth considering to provide incentives and mitigate risks to private savings, the recent reform of private pensions and the fiscal discipline envisaged over the medium term are steps in the right direction. Hence reforms to promote energy investments and to increase private and public sector savings are essential.

The current account deficit is one of the major macro economic problems of the Turkish economy and one of the major issues that Turkey must deal with to fulfill the economic criteria for European Union accession. Concerning the economic criteria for Turkey's European Union accession, Turkey is a functioning market economy. In 2012, the Turkish economy slowed down to an annual GDP growth of 2.2 percent from an unsustainable level of around 9 percent in the preceding two years. The slowdown was partly induced by a tightening of monetary policy and it was accompanied by a rebalancing of growth from domestic demand to foreign trade, a narrowing in the current account deficit and falling inflation. In the first quarter of 2013, the economy regained some momentum, but Turkey's financial markets and the Turkish lira have subsequently come under severe downward pressure in the context of anticipated changes in international monetary conditions, domestic political unrest and the civil war in neighbouring Syria. These developments underline the economic vulnerability associated with Turkey's still large current account deficit and they may put at risk the return to growth in the short term.
Sayfa/Page | 155

İGÜSBD

Cilt: 1 Sayı: 1

Haziran /

June 2014 
Sayfa/Page | 156 İGÜSBD Cilt: 1 Sayı: 1 Haziran / June 2014

\section{BIBLIOGRAPHY}

AKTAN, Coşkun Can \& İstiklal Y. Vural, Yeni Ekonomi ve Yeni Rekabet, Ankara: Ajans Türk Basın ve Basım A.Ş., 2004.

ASLANOĞLU, Erhan, 'Türkiye'nin Yabancı Sermaye Çekmede Etkinlik Arayışları.' İ. Öztürk (Ed.), Türkiye'nin Küreselleşmesi, Fırsatlar ve Tehditler, İstanbul: İstanbul Ticaret Odası Yayınları, 2008, s. 85-104.

CARBAUGH, Robert, International Economics, 7th Edition, Ohio: South Western College Publishing, 2000.

EDGERLY, David, 'Turkey's Current Account Deficit is Economy's Achilles Heel', Financial Times, 27 November 2013.

EĞİLMEZ, Mahfi \& Ercan Kumcu, Ekonomi Politikası: Teori ve Türkiye Uygulaması, 11. bs., Istanbul: Remzi Kitabevi, 2007.

EUROPEAN COMMISSION, Staff Working Document Turkey, 2013, Brussels, 16.10.2013 SWD, 2013.

EUROPEAN COMMISSION, EU Candidate and Pre-Accession Coumtries Economic Quarterly CCEQ 3/2013, Brussels: European Union, 2013.

EUROPEAN UNION, European Economy Occasional Papers 157, July 2013, 2013 Pre-accession Economic Programmes of Iceland, The Former Yugoslav Republic of Macedonia, Montenegro, Serbia and Turkey EU Commission's Overview and Assessmets, Brussels: European Union, 2013.

HOLMAN, Jill A., 'Is The Large U.S. Current Account Deficit Sustainable?', Economic Review, First Quarter, 2001, p. 5-23.

ICKES, B. 'The Current Account Balance', http://econ.la.psu.edu/ bickes/currentpartone.pdf, 2008.

IŞIK, Yusuf, 'Turkey's Current Account Balance: A Real Problem', İstanbul: Reflections Turkey, 2012, http://www.reflectionsturkey.com/?p=657. 
Turkey's Current Account Deficit Problem and Its Effects on The European Union...

KAYA, F., "Türkiye'de cari işlemler açı̆̆ı ve yabancı sermaye yatırımları ilişkisi” Yayımlanmamış Yüksek Lisans Tezi, İstanbul: Marmara Üniversitesi SBE, İktisat Anabilim Dalı Uluslararası İktisat Bilim Dalı, İstanbul, 2010.

ÖCAL, Tezer, Türkiye Ekonomisi, Ankara: Savaş Yayınevi, 2004.

ÖZ, Sumru, 'Current Account Deficit in Turkey: Macro and Micro Reasons and Suggested Solutions', International Investors Association YASED, 2011, s. 3-4.

HOEKMAN, B. \& Sübidey, T., Turkey: Economic Reform and Accession to the European Union, Washington, DC: World Bank and Centre for Economic Policy Research, 2005.

WES, M. \& Unal, C., 'Turkey Regular Economic Brief, Worldbank http://www.worldbank.org/content/dam/Worldbank/document/eca/trreb-eng-jul-2013.pdf, 2013.

World Investment Report, Geneva: UNCTAD United Nations, 2013.

YELDAN, Erinç, Küreselleşme sürecinde Türkiye ekonomisi, 12. bs., İstanbul: İletişim Yayınları, 2006.

YÜCEL, Fatih \& Rüstem Yanar, "Türkiye'de Cari İșlem Açıları Sürdürülebilir mi? Zaman Serileri Perspektifinden Bir Bakış', Çukurova Üniversitesi Sosyal Bilimler Enstitü sü Sosyal Bilimler Dergisi, 14 (2), 2005, s. 483-492.

ZAFIR, Ceran Zeynep \& Funda H. Sezgin, 'Analysis of the Effects of Foreign Direct Investment on the Financing of Current Account Deficits in Turkey', International Journal of Business and Social Science, 3(10), 2012, p. 68-78. 
Sayfa/Page | 158 İGÜSBD Cilt: 1 Sayı: 1 Haziran / June 2014

\section{Özet}

Gelişmekte olan ülkelerde uzun vadeli cari açıklar ekonomide ciddi sorunlara neden olabilir. Cari açık sorunu Türkiye'nin en önemli makro ekonomik sorunlarından biridir. Bu açı̆̆ın finanse edilmesi son yıllarda en çok tartışılan konulardan biri olmuştur. Türkiye, 1989 yılında 32 Sayılı Karar ile birlikte sermaye hareketleri üzerindeki her türlü denetimi kaldırmıș, 2000 'li yillarda gündeme gelen "enflasyon hedeflemesi" ulusal paranın değerlenmesi ile sonuçlanırken, bu süreç dış ticaret açıkları yoluyla cari açığın artmasına ve iç tasarrufların aşınmasına neden olmuştur. Cari açığın ortaya çıkışı hakkında iki farklı görüş bulunmaktadır. İlk görüşe göre, cari açık 2001 krizi sonrasında oluşan talep artışına bağlı olarak oluşmuştur. Diğer görüşe göre bu açık kısa vadeli spekülatif sermayenin akışını hızlandıran yüksek faiz oranları sonucu oluşan aşırı değerlenmiş yerel para biriminin bir sonucudur. Cari açık borç yoluyla finanse edildiği için ülkenin artan dış borcu ekonominin geleceğini tehdit etmektedir. Türkiye'de 2000'li yıllarla birlikte hızla artan cari açık sorununu besleyen belli başlı gelişmeler; enflasyon hedeflemesi sonucunda TL'nin aşırı değerlenmesi, enerjide artan dışa bağımlılık, dâhilde işleme rejimi ve 1996 yılında yürürlüğe giren Gümrük Birliği'nin gecikmiş etkileri olarak siralanabilir. Bu gelişmeler sonucunda üretimin ve ihracatın ithalata bağımlılı̆̆ yapısal bir nitelik kazanmış, 1990'lı yıllardaki benzer büyüme oranları 2000'li yıllarda daha fazla cari açılklarla sonuçlanmaya başlamıştır. Cari açık sorununun çözülmesi Türkiye'nin Avrupa Birliği'ne tam üyelik süreci için gerçekleştirmesi gereken ekonomik kriterlerden biridir. 2012'de uygulanmaya başlanan teşvik sistemi ve 2013'te uygulanmaya başlanan yeni Türk Ticaret Kanunu'nun ötesinde yatırım iklimini güçlendirmeye yönelik yapısal reformlar, rekabet edebilirliği, büyümeyi ve özel yatırımları arttırmanın yanı sıra doğrudan yabancı sermaye yatırımlarını arttırmak suretiyle cari açığın sürdürülebilir finansmanına da katkı sağlayacaktır. 